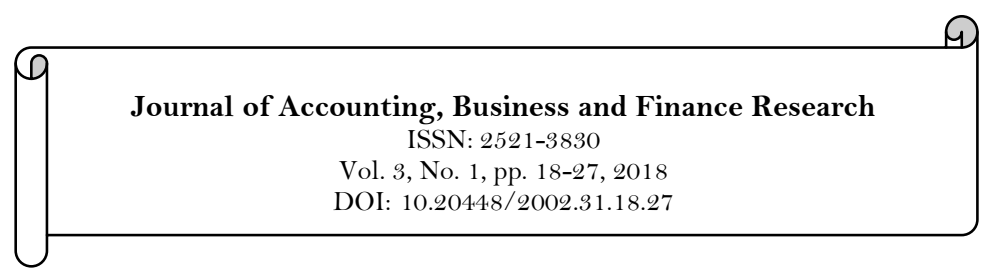

\title{
Influence of Promotion and Job Satisfaction on Employee Performance
}

\author{
Abdul Razak ${ }^{1}$ \\ Sarpan Sarpan ${ }^{2}$ \\ Ramlan Ramlan ${ }^{3}$ \\ ${ }^{1}$ Pemerintah Daerah Sulawesi Selatan. \\ ${ }^{2}$ Universitas Persada Indonesia YAI Jakarta Indonesia. \\ ${ }^{3}$ Bupati Mamasa Sulawesi Barat Indonesia.
}

\begin{tabular}{l|l}
\multicolumn{3}{|c}{ Abstract } & \\
\begin{tabular}{l|l} 
The purpose of this study is to know (1) Promotion of positions held; & Keywords: \\
(2) Employee job satisfaction; (3) employee performance; 4 The & Job promotion \\
influence of promotion and job satisfaction on employee performance & Job Sation \\
and Performance.
\end{tabular} \\
in Makasar Government Region, either simultaneously or partially. \\
The method used is descriptive survey method and explanatory. The & JEL Classification: \\
unit of analysis in this research is the employees of Makassar & M12; M51. \\
Government Region, with a sample of 50 people, and the method of & \\
analysis used is the frequency distribution and path analysis. Based & Licensed: \\
on the results of the analysis, then obtained as follows, Promotion & This work is licensed under a \\
positions Makassar Government Region has in accordance with the & Creative Commons Attribution \\
field and expertise, Job Satisfaction employees of Makasar & 4.0 License. \\
Government Region currently considered satisfied, Employees of & Publisher: \\
Makassar Government Region is considered to have a high enough & Scientific Publishing Institute \\
performance as well as job promotion and job satisfaction affect the & \\
performance of employees of Makassar Government Region, but & \\
when viewed partially, it turns out the promotion of dominant & \\
positions affects their performance. &
\end{tabular}

\section{Introduction}

The development of the business world, including the government sector in recent years, has shown rapid growth. The development is related to the national development in addition to the various facilities provided by the government by creating a better climate of the development of the government service in Indonesia. Makasar government region that serves as a means of autonomy and regional development that is a subsystem of the national service has a strategic role in achieving the goals of national development.

The Makasar government region itself has a strategic role in the public service development of a nation that performs its function as a means of mobilizing public service. Makasar government region until now still exist as a public trust institution to save service of exchange rate volatility and high priority. This can not be separated from the role of all employees from the start of the top management to the basic employees that always keep the harmony and hard work of all parties. Therefore, to strengthen the operational basis must be prepared tough human resources and qualified in anticipation of any changes that will occur.

Each institution including government institution in carrying out its various activities requires a variety of resources, human resources is one of the most important assets in the institution, which is also a partner institution in running the activities of the institution because those who produce and implement the staffing. Seeing so much the role of human resources as the main actors and also an input of productivity in the institution. However, in reality the performance of the employees is still relatively not to meet the expectations of management, this can be indicated by the slow service time for customers at the time of transaction, the delay adds form of personnel card, Less friendly and other events (Suggestion Box, 2013) according to Table 1 below this: 
Table-1. Indications of Performance Decrease.

\begin{tabular}{|c|c|c|}
\hline Indications of Performance Decrease & Measurement (\%) & Target (\%) \\
\hline Slow service time to public at the time of transaction & 70 & 85 \\
\hline The delay adds the form of personnel card & 72 & 85 \\
\hline Less friendly to publics & 80 & 85 \\
\hline Unclear information & 80 & 85 \\
\hline
\end{tabular}

Source: Suggestion Box 2013.

The implications of such working conditions, greatly affect the performance of employees, where based on the results of pre-surveys and daily observations obtained data and information that employee performance showed a declining trend. Documentation data performance appraisal results Human Resource Division Makasar Government Regionin the fourth quarter of 2010 reached 106.65\%; in the fourth quarter of 2011 reached $100,25 \%$ or down $6.4 \%$ from the previous year; in the fourth quarter of 2012 reached $98.40 \%$ or down $1.85 \%$ from the previous year.

In an effort to achieve the vision and mission of Makasar Government Region faced with the readiness of human resources institution must be able to compete with national and multi national that demand high professionalism.

The success of a company will depend on how employees can develop their skills, as well as for employees of Makasar Government Regionals a public service must have employees that are reliable, accurate, fast, friendly and convenient for consumers (publics Makasar Government Region), but based on preliminary survey results (2013), promotion of positions performed less precise, this is indicated by the mismatch between the skill and ability of the employee, so it is not uncommon to conduct training in advance as the employees that will be promoted and the level of satisfaction with employees of Makasar Government Region is relatively low, it can be seen from the complaints about the employees included in the suggestion box that has been provided and the level of service is partly less friendly.

The low performance of employees in addition to the problem Promotion, allegedly also because of the problem of job satisfaction, because promotion and job satisfaction can provide a strong impetus or motivation in the employees to work optimally to achieve high performance.

\section{Literature Review and Frame Work \\ 2.1. Promotion of Position}

Promotion is an important issue, not only in the selection / placement of the right people in the right place but also a boost for superiors / leaders to plan a policy of the field of personnel of motivating subordinates to develop themselves to achieve.

Promotion is an occurrence of labor transferred from a higher position in wages, responsibilities and / or organizational levels. According to Sikula (2000) as follows "Technically, a promotion is a movement within towards an organization of one position of another that involves either an increase or an increase in status."

Understanding of the above definition that technically promotion is a movement towards an organization of one position of another that involves both wage and status increases. Promotion will provide an important role in every employee because with the promotion means trust and recognition of the ability and skill of employees to maintain a high position.

While Siagian (2003) added in addition to seniority and work performance is also a combination of work performance and seniority. The purpose of such a combination is to consider whether the employee is worthy of promotion or not. This is the basis of the best and most appropriate promotion because it promotes the most experienced people of the good (clever) skills, so that promotional shortcomings based on experience / skills alone can are overcome.

\subsection{Work Satisfaction}

Every individual that works in every organization is naturally expecting to get everything that is beneficial and beneficial for his / her personal self. Their views on the conditions of their working environment and the feeling of satisfaction or dissatisfaction with the condition will affect their behaviour in work. As Robbins (2003) "We've previously defined satisfaction as an individual's general attitude to his or her job “.

Robbins statement is a sense of job satisfaction in general that describes that job satisfaction is the relationship between the individual with the work and the environment. Job satisfaction will arise if the individual likes his work and his environment and vice versa, there will arise a sense of dissatisfaction with an employee if he does not like his work, as stated by Cherrington (1989) "Job satisfaction refers basically to how much employees like their jobs ".

Another Human Resource Expert, Mangkunegara (2004) defines job satisfaction as a feeling that endorses or does not support employees related to their work or condition. Job-related feelings involving aspects such as salary / wages received, career development opportunities, relationships with other employees, job 
placements, occupations, organizational structure of the company, quality of supervision. While the feelings associated with himself, including age, health conditions, abilities, and education.

Other Human Resources Experts While Ivancevich (2001) define job satisfaction as follows: "Job satisfaction is the attitude to their employers about their jobs. While the meaning of the aspects of work are wages, opportunities, promotions, supervisors, and co-workers. Also derived from work environment factors such as policies and procedures, work group affiliations, and working conditions.

The relationship between an employee and his organization is called a psychological contract, because employees that submit their time, abilities, skills and endeavors also expect rewards from the organization. Regarding the contract with psychology, Schein as quoted by Gibson, John, and Donelly (2002) says that people have different expectations of organizations and organizations also have expectations of employees. These expectations include not only how much work must be done and how much it is paid, but also cover all the patterns of privileges, and the obligations to employees and the organization.

A person's job satisfaction basically depends on the difference between expectations, needs or values with what he or her feelings or perceptions have been gained or achieved through his work. A person will feel satisfied if there is no difference between the desired for his perception of reality, because the desired minimum threshold has been fulfilled.

Job satisfaction is an individual affective reaction to work and the work environment, which also includes attitudes and assessment of work. Each individual has a different level of satisfaction in accordance with the value system that applies to him (individual difference). The more aspects in the work that are in accordance with the desires and aspects of the individual self, then there is a tendency towards higher level of satisfaction with work

Based on the opinions on, the limit or definition of job satisfaction does not seem to have uniformity. However, there is no fundamental difference. In essence job satisfaction is a person's feelings or attitudes toward his work, where the attitude concerns the response to the difference of what he hopes with what are obtained from the reality of the workplace.

\subsection{Employee Performance}

Performance terms are derived from the words Job Performance or Actual Performance (achievement of work or actual achievement that someone achieved). Mangkunegara (2004) argues that performance is the result of work in quality and quantity achieved by an employee in performing their duties in accordance with the responsibilities given to him. Adapaun indicators used in this study include the quantity and quality of work, creativity, initiative and integrity of employees themselves While Kusrianto (1998) defines the performance is the comparison of results achieved with the role of labor unity time.

Employee performance is the ability given and shown by the employee while performing his duty, in other words what the performance of employees can be regarded as job performance shown by employees in the workplace, and employee performance can also be said as the ability shown by an employee in performing the task and responsibility.

According to Mitchell, 1978: 343, in Sedarmayanti (2004) employee performance includes several aspects, namely: (1) quality of work, (2) Proptness, (3) Initiative, (4) Capability, (5) Communication . These five aspects can be used as a measure in conducting assessment of one's performance level. Besides that, to conduct a measurement of performance, set Performance $=$ ability $\mathrm{x}$ motivation .

Kusrianto (1998) states that the performance of employees is the level of results that can be shown a person in the implementation of his work while Siagian (2003) explains that the performance is an achievement shown by employees, he is the result achieved in carrying out tasks assigned to him based on the skill of experience and sincerity and the time available.

That is, the performance of employees is the performance of work or achievement of employees who are implemented in daily work based on standard or sequence of assessments that have been established standards and measuring instruments is an indicator to determine whether an employee has high or low performance. Defined by the nature and type of work, the standard also serves as a measuring tool for providing accountability.

\subsection{Framework}

Based on the above opinion it can be said that the aspect of performance penialian not only revolves around the issue of traits (individual character) of an employee such as nature, temperament, intelligence, and so forth. However, more emphasis on things that are performance results (work), such as quality and quantity of work, timeliness and so forth. Even with the performance result allows for a more objective assessment.

However, not all types of work can be seen from the results quantitatively, so measurements with performance results will result in inaccurate data, for example, a receptionist can not be measured in achievement by the number of incoming guests, but can be judged by his ability to serve the guest. To that end, the selection of performance appraisal aspects should be tailored to the type of work performed by the assessed employee. Management must be able to create aspects of assessment that are closer to the truth about every work done. 
Based on the above statement, it is clear the influence over promotion and job satisfaction on the performance of employees. can be described in full diagram of the frame of thought as follows Figure 1:

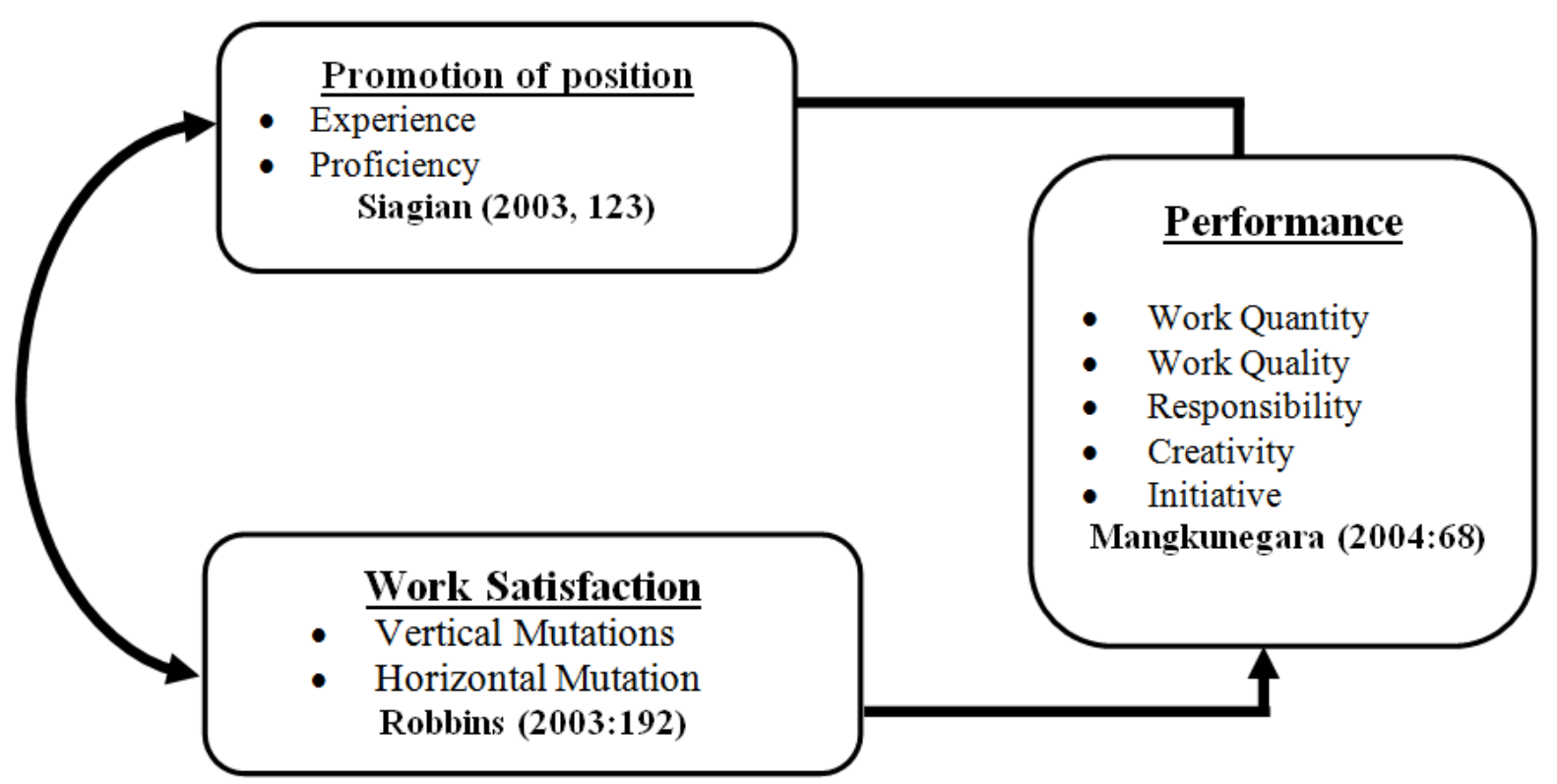

Source: Siagian (2003), Robbins (2003), Mangkunegara (2004)

Figure-1. Framework for Thinking.

\section{Research Methods}

The research method used is descriptive survey method and explanatory survey method. The type of investigation into this study is causality. The unit of analysis in this study is individuals, ie employees of Makasar Government Region. Time horizon in this study is cross-sectional, that is information about some population (respondent sample) is collected directly from the location empirically, with the aim to know the opinion of some population to the object under study.

Sources of data obtained in this study are interviews, observations, questionnaires and secondary data sources from the documentation or reports available on the related institutions such as: Annual Report Makassar Government Region in 2013. While the primary data in the form of promotion positions, job satisfaction and employee performance derived from empirical research from employees of Makasar Government Region.

The sampling technique used in this research is probability sampling, which is sampling technique which gives equal opportunity for every element (member) of population to be selected as member of sample. While the sampling method used is simple random sampling proportionally. Population of this research is employees of Makasar Government Region.

In this study, the sample size is determined by the form of statistical test to be used. The statistical test to be used is path analysis (Path Analysis), where the path coefficient is basically the correlation coefficient. Referring to the existing research to obtain the parameter $\rho$ in which research on the same topic has been done, it is obtained $\rho$ (the smallest correlation coefficient) $=0.305$. So with $\alpha=0.05$ and $\beta=0.05$ then obtained the sample size $(\mathrm{n})$ at least $49.34=50$ Employees of Makassar Government Region, which is considered representative of the population so that the research of the sample can describe the characteristics of the population.

\subsection{Hypothesis Analysis and Testing}

Before the data is analyzed, firstly done data processing. Data processing collected from the interviews and questionnaires can be grouped into 3 steps, namely: preparation, tabulation and application of data on research approach.

The preparation of the research involves collecting and checking the completeness of the questionnaire sheet and scoring in accordance with the established rating system. Closed questionnaire using ordinal scale 5, the value obtained is an indicator for the pair of independent variables $\mathrm{X}$ and the dependent variable $\mathrm{Y}$, namely as follows: $(\mathrm{X}, \mathrm{Y})$ which is assumed to be linear. Tabulation results data applied to the research approach used in accordance with the purpose of research.

To know the promotion of position and satisfaction, the data is processed by analyzing the attitude to respondents to the questionnaire items to see the results of the assessment (positive / negative) respondents on the implementation of variables studied by using Likert analysis. 
To obtain data onto qualitative variables (promotion and satisfaction), each variable is first spelled out into sub variables and each sub variable is operationalized into the indicator. Each indicator is measured by the size of the answer rating by ordinal scale.

The analysis used consisted of two types: (1) descriptive analysis especially for qualitative variables and (2) quantitative analysis, in the form of hypothesis test by using statistical test. Quantitative analysis is emphasized to reveal the behavior of research variables, whereas descriptive / qualitative analysis is used to explore the behavior of causal factors. The analysis method used is cross-sectional analysis. By using a combination of analytical methods can be obtained a comprehensive generalization.

Path analysis techniques require data requirements that have a measurement level of at least the interval.

To know correlation between job promotion variable, and job satisfaction influences between dimension / sub-variable of research on employee performance, tabulation result data applied to research approach that is with Path Analysis (Path Analysis) in Figure 2:

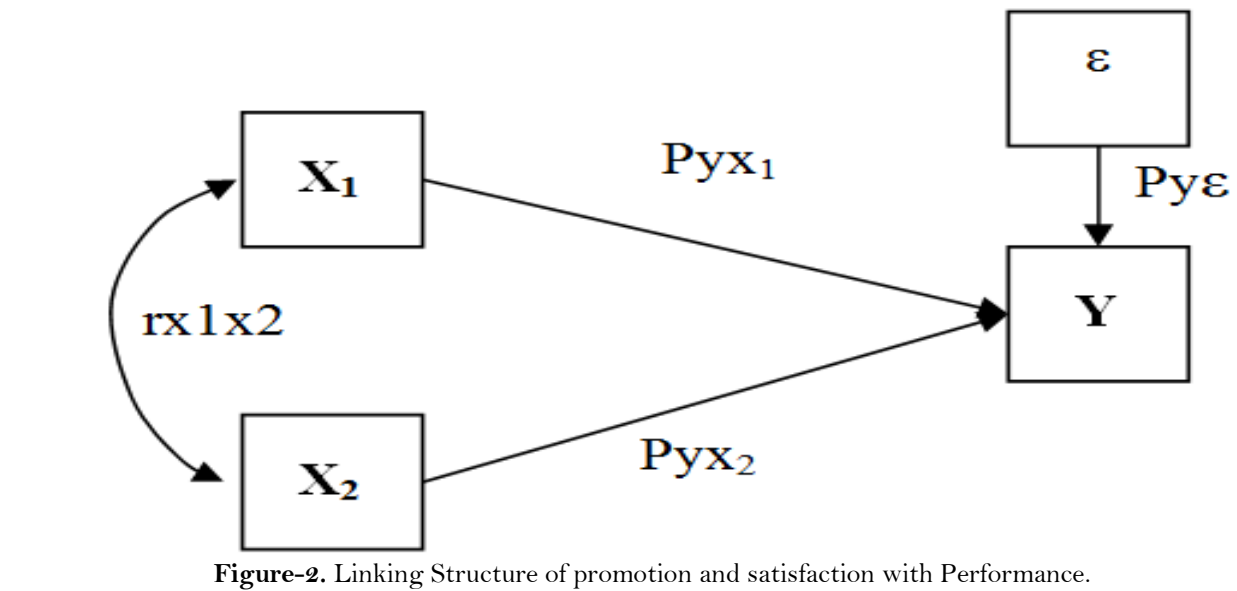

Source: (Nazir, 1988).

Based on the purpose of this study, the variables analyzed are the independent variables of promotion and job satisfaction (variables $\mathrm{X}_{1}$ and $\mathrm{X}_{2}$ ) while the dependent variable is the performance (variable $\mathrm{Y}$ ). In this study to be tested is how much influence of promotion and job satisfaction on performance, either simultaneously or partially. By taking into account the characteristics of the variables to be tested, the statistical tests used through regression and correlation calculations for both variables. Tests conducted are to determine the effect of independent variables $\mathrm{X}_{1}$ and $\mathrm{X}_{2}$ to $\mathrm{Y}$ either directly or indirectly.

The hypothesis proposed is as follows: the influence of promotion and job satisfaction on performance ,. If the research hypothesis is expressed in the statistical hypothesis is:

$\mathrm{H}_{\mathrm{o}}: \rho_{Y \mathrm{X}_{1}}=\rho_{Y \mathrm{X} 2}=0$
$\mathrm{H}_{1}: \rho_{Y \mathrm{X}_{1}}=\rho_{Y \mathrm{X} 2} \neq 0$

The simultaneous hypothesis submission is done by $\mathrm{F}$ test

Testing :

Hypothesis formula

Rejected Ho if $\mathrm{F}_{\text {count }} \geq \mathrm{F}_{\text {table }(0,05)(\mathrm{n}-\mathrm{k}-1)}$ There is influence of promotion and job satisfaction on performance Accept $\mathrm{Ho}$ if $\mathrm{F}_{\text {count }}<\mathrm{F}_{\text {table }(0,05)(\mathrm{n}-\mathrm{k}-1)}$ There is no influence of promotion and job satisfaction on performance The test statistic used is:

$$
F=\frac{(n-k-1) \sum_{i=1}^{k} p_{Y X} r_{Y X_{i}}}{k\left(1-\sum_{i=1}^{k} p_{Y X} r_{Y X}\right)}
$$

Test criterion, rejected $\mathrm{H}_{0}$ if $\mathrm{F}>\mathrm{F}_{\alpha ;(\mathrm{k}, \mathrm{n}-\mathrm{k}-1)}$ with $\mathrm{F}_{\alpha ;(\mathrm{k}, \mathrm{n}-\mathrm{k}-1)}$ obtained from the distribution table $\mathrm{F}$ with $\alpha=5 \%$, degrees of freedom, $\mathrm{db}_{1}=\mathrm{k}$, and $\mathrm{db}_{2}=\mathrm{n}-\mathrm{k}-1$.

If the general hypothesis (Simultaneous) in the study significant, then subsequent testing can be done for subhypothesis (Partial) that consists of:

-Promotion effect on employee performance Makasar Government Region.

- Job satisfaction affects the performance of employees of Makasar Government Region.

The calculation of Partial Path Analysis is as follows: 
1. Calculates multiple correlation coefficients $R_{Y \mathrm{X}_{1} X_{2}}$ by using the formula

$$
R_{Y X_{1} X_{2}}=\sqrt{\frac{R_{Y X_{1}}^{2}+R_{Y X_{2}}^{2}-2 R_{Y X_{1}} R_{Y X_{2}} R_{X_{1} X_{2}}}{1-R_{X_{1} X_{2}}^{2}}}
$$

2. Determine the coefficient of causality $\mathrm{r}_{\mathrm{x} 1 \mathrm{x} 2}, \rho_{Y \mathrm{X}_{1}}, \rho_{Y \mathrm{X} 2}$

3. Calculates environmental influences (more) $\rho \varepsilon_{Y}=\sqrt{1-R_{X_{1} X_{2}}}$

4. Acceptance or Rejected Decisions Ho

a. Partial operational hypothesis formula $\left(\rho_{Y \mathrm{X}_{1}}\right)$

Ho: $\rho_{Y \mathrm{X}_{1}}=0$, There is no promotional effect on performance

Hi: $\rho_{Y \mathrm{X}_{1}} \neq 0$, There are promotional effects on performance

b. Partial operational hypothesis formula $\left(\rho_{Y \mathrm{X} 2}\right)$

Ho : $\rho_{Y \mathrm{X} 2}=0$, There is no effect of job satisfaction on performance

Hi : $\rho_{Y \mathrm{X} 2} \neq 0$, There is influence of job satisfaction on performance

c. Decision criteria

Rejected Ho if $t_{\text {count }} \geq t_{\text {table }(0,05)(n-k-1)}$

Accepted Ho if tcount $<t_{\text {table }(0,05)(n-k-1)}$

$$
\text { where } t=\frac{P_{Y \mathrm{X}_{\mathrm{i}}}}{\sqrt{\frac{\left(1-\mathrm{R}_{Y\left(\mathrm{X}_{1} \mathrm{X}_{2}\right) \cdot C_{i i}}^{2}\right.}{(n-\mathrm{k}-1)}}}
$$

Rejected $\mathrm{H}_{0}$, if $\mathrm{t}_{0 \mathrm{i}} \geq \mathrm{t}(\alpha ; n-\mathrm{k}-1)$

\section{Research Result and Discussion}

To reveal the influence of a variable or set of variables against other variables, can be used Path Analysis (Path Analysis) that has been developed Sewall Wright. In the analysis of this path the magnitude of the influence of a variable on other variables, both direct and indirect can be known. Before making a decision on the magnitude of the influence of a variable on other variables, the first tested the hypothesis, either testing as a whole or individually.

To know whether the free variables of promotion position $\left(\mathrm{X}_{1}\right)$ and job satisfaction $\left(\mathrm{X}_{2}\right)$ simultaneously affect the performance of employees (Y) Makassar Government Region, conducted by using path analysis and software used is SPSS release 12. The step is to calculate the correlation between variables, so obtained as the table below.

Table-2. Interrelated Correlation Matrix.

\begin{tabular}{l|l|l}
\hline & $\mathrm{X}_{1}$ & $\mathrm{X}_{2}$ \\
\hline $\mathrm{X}_{1}$ & 1,000 & 0,471 \\
\hline $\mathbf{X}_{2}$ & 0,471 & 1,000 \\
\hline \multicolumn{2}{l}{ Source: SPSS output results. }
\end{tabular}

Based on the above Table 2 is a correlation matrix between variables that indicate the magnitude of the relationship between each variable either dependent or independent. The proportion of the path diagram is three independent variables $(\mathrm{X})$ that have relationships between variables, and each independent variable (X), and the collorable relationship of the variable outside $(\mathrm{X})$ residue to the dependent variable $\mathrm{Y}$. The steps to calculate path analysis (path analysis) are as follows:

$\mathrm{P}_{\mathrm{Yxi}}=\sum_{j=1}^{\mathrm{k}} \mathrm{CR}_{\mathrm{ij}} \mathrm{r}_{\mathrm{YX}} \quad \mathrm{I}=1,2$

And overall influence $\mathrm{X}_{1}$, dan $\mathrm{X}_{2}$

$$
\begin{aligned}
R_{Y X_{1} X_{2} \ldots X_{7}}^{2} & =\sum_{i=1}^{k} p_{Y X_{i}} r_{Y X_{i}} \\
& =0,427
\end{aligned}
$$

while the coefficient of the other variable path of the variable $\mathrm{X}_{1}$, and $\mathrm{X}_{2}$ is determined through: 
$\mathrm{PY} 1 \varepsilon 1_{1}=\longdiv { 1 - R _ { Y X 1 X 2 } }$

$=0,757$

mean that the influence of variables $\mathrm{X}_{1}$ and $\mathrm{X}_{2}$ together to the variable $\mathrm{Y}$ of 0.427 or $42.7 \%$ variables $\mathrm{X}_{1}$ and $\mathrm{X}_{2}$ jointly affect $\mathrm{Y}$, and the remaining 0.573 or $57.3 \%$ influenced by other variables not included in the study

Based on the theoretical framework that there is a positive influence over Promotion and job satisfaction on Employee Performance Makassar Government Region, will then test the overall hypothesis with the following form:

1) Hypothesis Testing Simultaneously

To know whether the independent variables, namely Promotion position $\left(\mathrm{X}_{1}\right)$, and Job Satisfaction $\left(\mathrm{X}_{2}\right)$ simultaneously affect the performance of employees (Y) Makassar Government Region, where the hypothesis statistics can be expressed in the form as follows:

Ho: Pyx $1=\operatorname{Pyx} 2=0$

Job promotion $\left(\mathrm{X}_{1}\right)$ and Job Satisfaction $\left(\mathrm{X}_{2}\right)$ simultaneously have no effect on Employee Performance

(Y) Makasar Government Region

$\mathrm{H}_{1}$ : At least there is a Pyxi $\neq 0$

Job promotion $\left(\mathrm{X}_{1}\right)$ and Job Satisfaction $\left(\mathrm{X}_{2}\right)$ simultaneously have a significant effect on Employee Performance (Y) Makasar Government Region.

Hypothesis testing is done through $\mathrm{F}$ test statistic, with the terms received Ho if $\mathrm{F}_{\text {count }}<\mathrm{F}_{\text {table, }}$

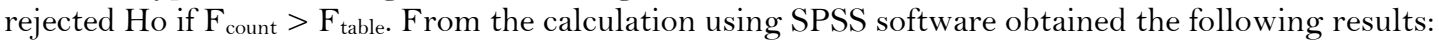

Table-3. Simultaneous Testing.

\begin{tabular}{l|l|l|l}
\hline Alternative Hypothesis & $\mathbf{F}_{\text {count }}$ & $\mathbf{F}_{\text {table }} \mathbf{( 5 \% )}$ & Conclusions \\
\hline $\begin{array}{l}\left(\mathrm{X}_{1}, \text { dan } \mathrm{X}_{2}\right) \text { simultaneously } \\
\text { affecting Y }\end{array}$ & 17,545 & & \\
\hline
\end{tabular}

Based on Table 3 the results of the calculation, it turns out $\mathrm{F}$ value of 17.545 is greater than $\mathrm{t}$ table 3.23 (Fo> F *: (k, nk-1) (17.545> 3.23), so the hypothesis accepted or Ho rejected. That means individual testing for hypothesis can continue to be done ie:

2) Individual Hypothesis Testing

Individual testing is done when testing simultaneously rejecting the null hypothesis means that at least one coefficient path is not equal to zero. This test is used to know or test the influence of each independent variable whether individual significance or not. Since the overall test yields significant tests, further analysis is performed by individual testing (partial testing).

$\mathrm{H}_{\mathrm{o}}=$ Pyxi $=0$

$\mathrm{H}_{1}=$ Pyxi $>0$

Test statistics for each hypothesis

$$
t_{0 i}=\frac{p_{\mathrm{mi} i}}{\sqrt{\frac{\left(1-R_{Y}{ }^{2} x_{1} x_{2} X_{3}\right) C r_{i i}}{n-k-1}}} \quad, i=1,2,3, \quad \begin{aligned}
& \text { (Output SPSS see attachment) } \\
& \text { Rejected } \mathrm{H}_{\mathrm{o}}, \text { if } \mathrm{t}_{\mathrm{oi}}>\mathrm{t}_{1-\alpha(\mathrm{n}-\mathrm{k}-1)}
\end{aligned}
$$

Using the distribution table $t$ obtained: (SPSS results according to the attachment)

$\mathrm{t}_{0,95(50-2-1)}=\mathrm{t}_{\text {table }}=1,645$

Table-4. Testing hypotheses $\mathrm{X}_{1}$ and $\mathrm{X}_{2}$ to $\mathrm{Y}$.

\begin{tabular}{l|l|l|l|l}
\hline $\begin{array}{l}\text { Path } \\
\text { Coefficient }\end{array}$ & $\begin{array}{l}\text { Path } \\
\text { Coefficient }\end{array}$ & $\mathbf{T}_{\text {count }}$ & $\mathbf{T}_{\text {table }}$ & Conclusions \\
\hline PYX $_{1}$ & 0,522 & 4,170 & 1,645 & $\begin{array}{l}\text { Ho rejected } \\
\text { Positive influence Position promotion on } \\
\text { employee performance Makasar Government } \\
\text { Region }\end{array}$ \\
\hline PYX $_{2}$ & 0,218 & 2,746 & 1,645 & $\begin{array}{l}\text { Ho rejected } \\
\text { There is a positive influence Job satisfaction } \\
\text { on Employee Performance Makasar } \\
\text { Government Region }\end{array}$ \\
\hline Source: calculation results.
\end{tabular}

Based on the calculation of coefficient of variable path $\left(\mathrm{X}_{1}\right)$ and $\left(\mathrm{X}_{2}\right)$ to $(\mathrm{Y})$, obtained by using SPSS release 12 for windows program, Thus according to the decision rule, that $t_{\text {count }}$ prices fall in Ho rejected means 
significant path coefficient, so the path diagram does not change. Conceptually can be explained that all aspects of job promotion and job satisfaction aspects positively affect employee performance Makasar Government Region.

From the results of hypothesis testing for variables $\mathrm{X}$ and $\mathrm{Y}$ there is a direct relationship between the variables Promotion position and Job Satisfaction on Employee Performance Makasar Government Region, a complete diagram of causal relationships of variables $\mathrm{X}_{1}$ and $\mathrm{X} 2$ to $\mathrm{Y}$ are as follows:

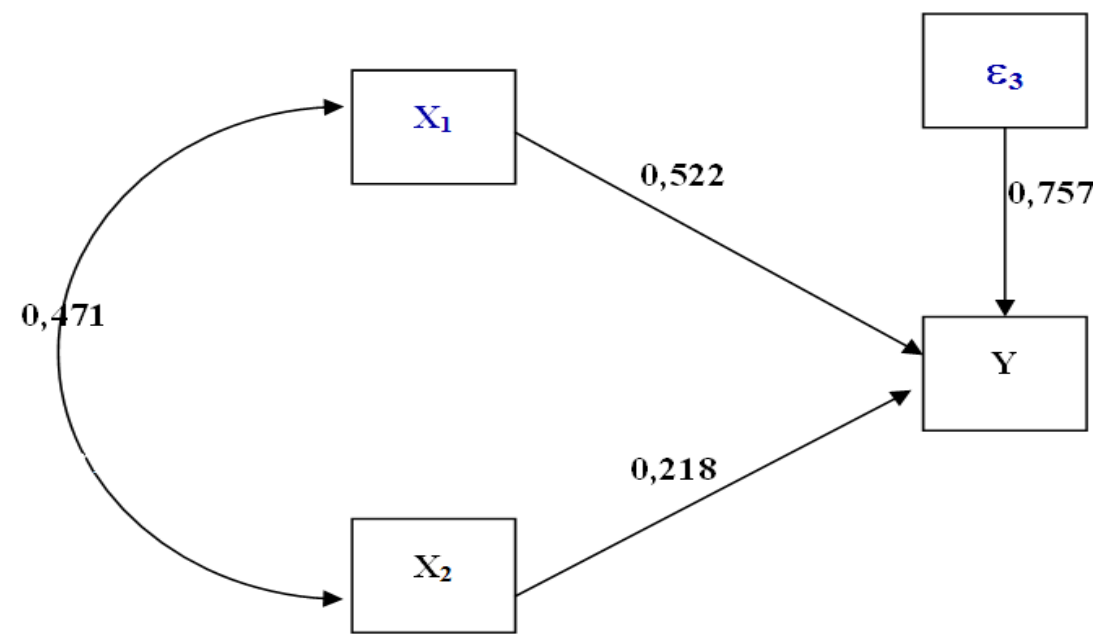

Figure-3. Line Chart of Promotion position $\left(\mathrm{X}_{1}\right)$ and Job Satisfaction $\left(\mathrm{X}_{2}\right)$ on Employee Performance $(\mathrm{Y})$. Source: SPSS Result.

From Figure 3 the structural picture of causal relationships between variables with the values of the above structure parameters, the influence to the variable causes to the variable, the influence of job promotion and job satisfaction on employee performance Makasar Government Regionis :

Table-5. Effects of Variables $\mathrm{X}_{1}$ and $\mathrm{X}_{2}$ to $\mathrm{Y}$ and Influencies Outsider Variables $\mathrm{X}_{1}$ and $\mathrm{X}_{2}$.

\begin{tabular}{l|c|c}
\hline Interpretation of Path Analysis & Influence & $\%$ \\
\hline Information & 0,427 & 42,7 \\
\hline Influence $\mathrm{X}_{1}, \mathrm{X}_{2}$ to $\mathrm{Y}$ & 0,573 & 57,3 \\
\hline Influence Outside $\mathrm{X}_{1}$, and $\mathrm{X}_{2}$ & & 100 \\
\hline amount & &
\end{tabular}

From the test results can be seen that job promotion and job satisfaction influence on employee performance Makasar Government Regionat 42.7\%, while the rest of 57.3\% influenced by other factors not examined by the author. However, when viewed partially Promotion more dominant position affects employee performance Makasar Government Regionthan Job Satisfaction. This can be understood because every indicator of job promotion and job satisfaction made an aspect of measurement Performance of employees of Makasar Government Region.

Based on the above calculation, it can be revealed that the Training on Employee Performance either directly or indirectly at Makasar Government Region can be seen in Table 6 below:

Table-6. Direct and Indirect Effect of Promotion on Employee Performance.

\begin{tabular}{l|l|c|c}
\hline Interpretation of Path Analysis \\
\hline Desc. & & Influence & $\%$ \\
\hline $\mathbf{X}_{1}$ & Direct influence to Y & 0.272484 & 27.25 \\
\hline & Indirect influence through $\mathrm{X}_{2}$ to Y & 0.053598 & 5.36 \\
\hline Amount & \multicolumn{2}{l}{0.3261} & 32.61 \\
\hline
\end{tabular}

From the Table 6 above can be seen that the contribution of job promotion on employee performance directly by $27.25 \%$ with $t$ count coefficient of 4.170 , while for $t$ table value at significance level $\alpha(0,05)=$ 1.645 , because $\mathrm{t}$ count $>\mathrm{t}$ table, and indirectly through variable job satisfaction of $5.36 \%$. While the contribution to job promotion to the performance of employees as a whole reach $32.61 \%$, where the better promotions positions carried out will result from increased employee performance. This description has also answered the hypothesis of promotion positions partially to affect the performance of employees. 
The path coefficient indicates a positive and significant value. From the above calculation results, it can be revealed that the effect of job satisfaction from the performance of employees either directly or indirectly can be seen in Table 7 below:

Table-7. Direct and Indirect Influence of Job Satisfaction on Employee Performance.

\begin{tabular}{l|l|c|c}
\hline Interpretation of Path Analysis & Influence & \% \\
\hline Descript. & & 0.0475 & 4.75 \\
\hline $\mathbf{X}_{2}$ & Direct influence to Y & 0.0536 & 5.36 \\
\hline & Indirect influence through $\mathrm{X}_{1}$ to Y & 0.1011 & 10.11 \\
\hline amount & &
\end{tabular}

From the table above can be seen that the contribution of job satisfaction on the performance of employees directly $4.75 \%$, with $t$ count coefficient of 2.746 , while for the t table value at the level of significance $\alpha(0.05)=$ 1.68 , because $t$ count $>t$ table, and indirectly through variable promotion promotion of $11.97 \%$. While the contribution to job satisfaction with the performance of employees as a whole reach 10.11\%, where the condition shows that the variable of job satisfaction is very strong or very closely influence over the achievement of employee performance. So, the more discipline teachers in carrying out their duties will provide a positive correlation between improving its performance. This description partially has answered the hypothesis of this study, that the partial job satisfaction effects on employee performance.

With the implementation of promotions conducted regularly will improve the performance so that also increased motivation. The results showed that there is a significant and positive influence between the implementation of promotion on employee performance, meaning the better the implementation of promotion, the performance will increase. so that Makasar Government Regionthrough the HR Department can emphasize the promotion to improve employee performance, taking into account the employment period and the level of the employee. This is in accordance with the opinion of Siagians (2002) adds in addition to seniority and work performance as well as a combination of work performance and seniority. The purpose of such a combination is to consider whether the employee is worthy of promotion or not. This is the basis of the best and most appropriate promotion because it promotes the most experienced people of the good (clever) skills, so that promotional shortcomings based on experience / skills alone can are overcome.

From result of research indicate that generally job satisfaction at Makassar Government Region is quite good, it is in the opinion of Bernadin and Russel (2003) that: "employee performance depends on the ability, work effort and employment opportunities that can be assessed from out put generated from employee job satisfaction itself, means job satisfaction perceived by the Employee has a contribution and influence on employee performance. Therefore, in an effort to improve the performance of employees, need improvement and improvement of job satisfaction factors, because job satisfaction is closely related to performance improvement, job satisfaction perceived Employees feel satisfied, is expected to increase also performance Employees.

The result of hypothesis tests for promotion and job satisfaction have an effect on employee performance and have significant influence. So with the promoted employees willing to work hard and desire to achieve maximum work result, can improve its performance effectively. Thus it can be said that the suitability of promotion of positions will affect the satisfaction so that the performance of employees will increase.

\section{Conclusions}

With the starting point of the discussion of the problem, theoretical basis, empirical data analysis, hypothesis test results, then in the last chapter in this study will be presented some conclusions are as follows:

1. Promotion of Makassar Government Region has been in accordance with the field and expertise, but need to be considered in terms of creativity in a job of implementing promotion and placement so that employees that are promoted to be satisfied and the wheel of the organization and the company will run well

2. Job satisfaction with Makasar Government Regioncurrently considered quite satisfied, but there are things to note, namely the satisfaction with interpersonal relationships

3. Employee of Makassar Government Region is considered to have a high enough performance, but things that must be improved is a good personal integrity soul or role in a group.

4. Job promotion and job satisfaction affect the performance of employees of Makasar Government Region, but when viewed partially, it turns out the dominant position promotion affects their performance. Partially, the influence of promotion and job satisfaction on performance is as follows:

a. Promotion of employees significantly influences on performance, it shows that the promotion of employees will determine the motivation of employee work, if the implementation of the campaign appropriate / in accordance with the experience and skills of employees.

b. Job satisfaction significantly affects the performance of employees; therefore, performance will increase if employees have been satisfied. 


\section{References}

Bernadin, J. H., \& Russel, J. E. A. (2003). Human resource management. New York: Mc Graw Hill Inc.

Cherrington, D. J. (1989). Organizational behavior: The management of individual and organizational performance. Boston: Allyn and Bacon.

Gibson, J. L., John, M. I., \& Donelly, J. H. (2002). Organization and management, behavior, structure, process. Jakarta: Erlangga: Translation. Djoerban Wahid.

Ivancevich, J. M. (2001). Human resource (8th ed.): The McGraw-Hill Companies, Inc.

Kusrianto, N. (1998). Social Research Procedure. In Sartini Pawe. The Role of Home Industry in Increasing the Income of Roworena Village Community. Thesis.

Mangkunegara, A. P. (2004). Human resource management company. Bandung: PT Remaja Rosdakarya.

Nazir, M. (1988). Metode penelitian. Jakarta: Ghalia Indonesia.

Robbins, S. P. (2003). Organization behavior (9th ed.). New Jersey: Prentice - Hall International Inc.

Sedarmayanti. (2004). Development of employee personality. Bandung: Mandar Maju.

Siagian, P. S. (2003). Tips for increasing work productivity. Jakarta: Rineka Cipta. First Print.

Siagians, P. S. (2002). Human resource management. Jakarta: CV Haji Masagung.

Sikula, A. E. (2000). Personnel administration and human resources management. Toronto: John Wiley \& Sons, Inc. 